\title{
TLR-mediated activation of peripheral blood monocyte phagocytosis in patients with multiple sclerosis
}

\author{
A. I. Skliar ${ }^{\mathbb{D}} * 1, \mathrm{B,D}, \mathrm{E}$, O. M. Koliada ${ }^{\mathbb{D}}{ }^{2, B, C, D}$, N. I. Vdovichenko ${ }^{1, B, C, D}$, T. I. Koliada ${ }^{1, A, C, E, F}$
}

${ }^{1} \mathrm{SI}$ "Mechnikov Institute of Microbiology and Immunology of the National Academy of Medical Sciences of Ukraine", Kharkiv, ${ }^{2}$ Kharkiv National Medical University, Ukraine

A - research concept and design; B - collection and/or assembly of data; C - data analysis and interpretation; D - writing the article; $\mathrm{E}$ - critical revision of the article; $\mathrm{F}$ - final approval of the article

Key words:

multiple sclerosis,

IFN- $\beta$,

phagocytic activity

of monocytes,

Toll-like receptors.

Pathologia

2020; 17 (2), 228-233

*E-mail:

labimmun@gmail.com
The aim of the study: to reveal peculiarities of the phagocytic activity of TLR4, TLR7/8-activated monocytes of peripheral blood, depending on the type of multiple sclerosis and clinical effectiveness of the treatment.

Material and methods. E. coli or ssRNA40/LyoVec lipopolysaccharide as TLR4 and TLR7/8 agonists were added to the monocyte-enriched cell suspension, respectively, and incubated for 24 hours at $t 37^{\circ} \mathrm{C}$ under an atmosphere of $5 \% \mathrm{CO}_{2}$. In parallel series, ram erythrocytes (RE) sensitized with hemolytic serum and inactivated $C$. albicans cells were used as phagocytosis objects; the incubation time was 30 minutes. The phagocytic index was calculated as the percentage of phagocytic monocytes and the phagocytic number as the ratio of the total number of absorbed REs or $C$. albicans cells to the number of monocytes that entered into phagocytosis. The study presents the results of examination of 58 patients with recurring remitting (RRMS) and 36 patients with progressive (PMS) multiple sclerosis.

Results. The differences in the activation mechanisms of peripheral blood monocytes in patients with PC, which consist in different phagocytic activity in response to stimulation of TLR4 and TLR 7/8 depending on the disease conditions, were presented. Phagocytic activity lesions of monocytes were observed both in patients with RRMS and PMS, associated mainly with FcR-mediated mechanisms of phagocytosis.

IFN- $\beta$ therapy in patients with RRMS led to the correction of such disorders in patients with high treatment efficacy (responders), and TLR7/8-mediated activation of monocytes was accompanied by an increase in the number of phagocytic cells. In patients with low efficacy of IFN- $\beta$ therapy (nonresponders), the nature of changes in the phagocytic activity of stimulated monocytes indicated a decrease in the functional reserve with regard to FcR-mediated phagocytosis.

Conclusions. The obtained results indicate differences in phagocytic activity indices during stimulation of TLR4 and TLR7/8 and may indicate the presence of functional and phenotypic alterations of peripheral blood monocytes depending on the effectiveness of MS treatment.
Ключові слова: розсіяний склероз, IFN- $\beta$, фагоцитарна активність моноцитів, Tоll-подібні рецептори.

Патологія. 2020. T. 17, № 2(49)

C. $228-233$

\section{TLR-опосередкована активація фагоцитозу моноцитів периферичної крові у хворих на розсіяний скмероз}

\section{А. І. Скляр, О. М. Коляда, Н. І. Вдовіченко, Т. І. Коляда}

Мета роботи - визначити особливості фрагоцитарної активності TLR4, TLR7/8-активованих моноцитів периферичної крові залежно від типу перебігу розсіяного склерозу та ефективності лікування.

Матеріали та методи. У збагачену моноцитами суспензію клітин додавали ліпополісахарид E. coli aбo ssRNA40/ LyoVec як агоністи TLR4 та TLR7/8 відповідно та інкубували протягом 24 годин за t $37^{\circ} \mathrm{C}$ при атмосфері $5 \% \mathrm{CO}_{2}$. Як об'єкт фрагоцитозу використали в паралельних серіях сенсибілізовані гемолітичною сироваткою еритроцити барана (ЕБ) та інактивовані клітини C. albicans, час інкубації - 30 хвилин. Розраховували фрагоцитарний індекс (ФІ) як відсоток моноцитів, що фагоцитують, та фагоцитарне число (ФЧ) як відношення загальної кількості поглинутих ЕБ або клітин C. albicans до числа моноцитів, що вступили в фагоцитоз. Наведені результати обстеження 58 пацієнтів із рецидивно-ремітувальним (РРPС) і 36 осіб із типом (ПРС) розсіяного склерозу, що прогресує.

Результати. Показано різну фагоцитарну активність моноцитів периферичної крові у відповідь на стимуляцію TLR4 та TLR7/8 у хворих на РC, що свідчить про особливості механізмів активації мононуклеарних клітин залежно від типу перебігу захворювання.

Пригнічення фагоцитарної активності моноцитів спостерігали в пацієнтів із РPРС, більше - у хворих на ПРС, що передусім пов'язано із FCR-опосередкованими механізмами фагоцитозу.

Ефективність лікування IFN- $\beta$ у хворих на PPPC супроводжувалася нормалізацією фрагоцитарних реакцій моноцитів, i TLR7/8-опосередкована активація моноцитів - підвищенням кількості клітин, що фрагоцитують.

У пацієнтів із незадовільними результатами лікування IFN- $\beta$ зниження фагоцитарної активності стимульованих моноцитів свідчить про зниження функціонального резерву щодо FcR-опосередкованого фагоцитозу.

Висновки. Результати вказують на різну активність мононуклеарних клітин при стимуляції TLR4, TLR7/8 і можуть свідчити про наявність функціональних і фенотипових альтерацій моноцитів периферичної крові залежно від ефективності лікування РС. 


\section{TLR-опосредованная активация фагоцитоза моноцитов периферической крови у больных рассеянным скиерозом}

\section{А. И. Скляр, О. Н. Коляда, Н. И. ВАовиченко, Т. И. Коляда}

Цель работы - определить особенности фагоцитарной активности TLR4, TLR7/8-активированных моноцитов периферической крови в зависимости от типа течения рассеянного склероза и эффективности лечения.

Материалы и методы. В обогащенную моноцитами суспензию клеток добавляли липополисахарид E. coli или ssRNA40/LyoVec в качестве агонистов TLR4 и TLR7/8 соответственно и инкубировали в течение 24 часов при t $37^{\circ} \mathrm{C}$ при атмосфере $5 \% \mathrm{CO}_{2}$. В качестве объекта фагоцитоза использовали в параллельных сериях сенсибилизированные гемолитической сывороткой эритроциты барана (ЭБ) и инактивированные клетки C. albicans, время инкубации - 30 минут. Рассчитывали фагоцитарный индекс (ФИ) как процент фагоцитирующих моноцитов, фагоцитарное число (ФЧ) как отношение общего количества поглощенных ЭБ или клеток $C$. albicans к числу моноцитов, вступивших в фагоцитоз. Представлены результаты обследования 58 пациентов с рецидивирующим-ремиттирующим (PPPC) и 36 человек с прогрессирующим типом (ПРС) рассеянного склероза.

Результаты. Показана разная фрагоцитарная активность моноцитов периферической крови в ответ на стимуляцию TLR4 и TLR7/8 у больных PC, что показывает особенности механизмов активации мононуклеарных клеток в зависимости от типа течения заболевания. Угнетение фагоцитарной активности моноцитов наблюдали у пациентов с PPPC, в большей степени - у больных ПРС, что в основном связано c FcR-опосредованными механизмами фагоцитоза.

Эффрективность лечения IFN- $\beta$ у больных PPPC сопровождалась нормализацией фагоцитарных реакций моноцитов, и TLR7/8-опосредованная активация моноцитов сопровождалась повышением количества фрагоцитирующих клеток. У пациентов с неудовлетворительными результатами лечения IFN- $\beta$ снижение фагоцитарной активности стимулированных моноцитов указывает на снижение их фрункционального резерва в отношении FcR-опосредованного фрагоцитоза.

Выводы. Результаты указывают на разную активность мононуклеарных клеток при стимуляции TLR4 и TLR7/8 и могут свидетельствовать о наличии функциональных и фенотипических альтераций моноцитов периферической крови в зависимости от эфффективности лечения РС.

Mononuclear phagocytes are known to be one of the initiators of inflammatory responses in various pathological conditions, including autoimmune demyelinating diseases. Therefore, the study of the role of these immune cells in the development of inflammatory processes in microglia may be a promising direction in investigating the pathogenic mechanisms involved in multiple sclerosis (MS) [1-4].

Acting as direct orthologues of glial cells of the central nervous system, peripheral blood monocytes are a valuable model system for studying the role of microglia in neurodegeneration [2]. Moreover, it is known that the functional properties of phagocytic cells may change in the course of inflammation, indicating that there is a direct link between these processes $[1,4,5]$.

TLR-mediated activation (via Toll-like receptors) of peripheral blood monocytes is one of the physiological mechanisms of innate immunity resulting in the involvement of these cells in the process of immune response formation. Stimulation of TLRs of different types by agonists specific to them causes activation of the signaling pathway cascade, which in turn leads to the development of general and subpopulation-dependent functional reactions inherent in peripheral blood monocytes. It is known that TLR4 plays an important role in the development of inflammation and is part of one of the oldest signaling mechanisms of innate immunity [6-8], and an important role of TLR7/8 signaling in the development of neuroinflammatory processes has been shown $[9,10]$.

Treatment of multiple sclerosis depends on the clinical form and nature of the disease. Treatment of exacerbations and progressive forms of MS involves administration of corticosteroids and cytostatics. Other pathogenic agents that can change the course of the disease and improve the survival of patients currently include inter- ferons, synthetic glatiramer acetate polymer, and immunotherapy using monoclonal antibodies against specific integrin molecules [11].

It is known that monocytes are one of the most sensitive cells of the immune system capable of responding even to minor pathological processes in the body at the earliest stages of the immune response. Therefore, the analysis of the functional status of peripheral blood monocytes can be informative both for assessing the course of the disease and predicting the effectiveness of therapy [1,5,7-13]. All this indicates that mononuclear cells are unique and promising object that can be used as a biomarker to predict the course of multiple sclerosis.

\section{Aim}

The aim of the study was to reveal peculiarities of the phagocytic activity of TLR4, TLR7/8-activated monocytes of peripheral blood, depending on the type of multiple sclerosis and clinical effectiveness of the treatment.

\section{Materials and methods}

The study involved 94 patients with multiple sclerosis undergoing outpatient and inpatient treatment in the department of neuroinfection and multiple sclerosis of the State Institution "Institute of Neurology, Psychiatry and Narcology of the National Academy of Medical Sciences of Ukraine". The study included 39 men and 55 women with a mean age of $34.8 \pm 7.4$ and $42.2 \pm 7.7$ years, respectively, as well as 27 practically healthy subjects (control group) of both sexes with a mean age of $35.3 \pm 5.4$ years. The study included patients with a verified diagnosis of multiple sclerosis (G35 code according to ICD-10 - Multiple Sclerosis). According to
Ключевые слова: рассеянный склероз, IFN- $\beta$, фагоцитарная активность моноцитов, Toll-подобные рецепторы.

Патология. 2020.

T. 17, № 2(49). C. $228-233$ 


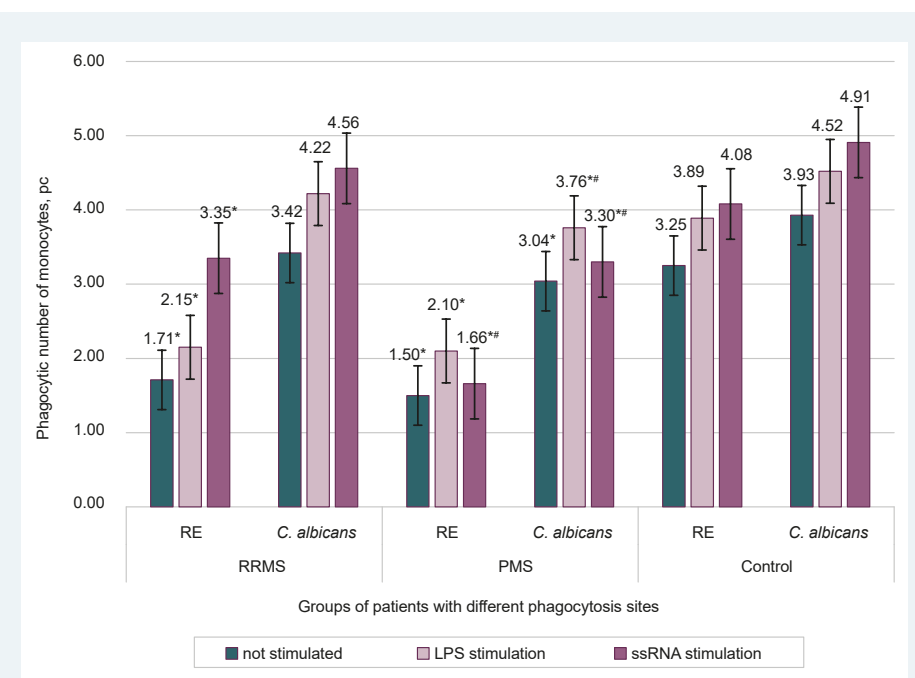

Fig. 1. Phagocytic index of peripheral blood monocytes relative to ram erythrocytes and $C$. albicans in patients with different types of MS.

*: $\mathrm{P}<0.05$ when compared with control group; \#: $\mathrm{P}<0.05$ when compared between patients with recurrent remitting MS and progressive MS

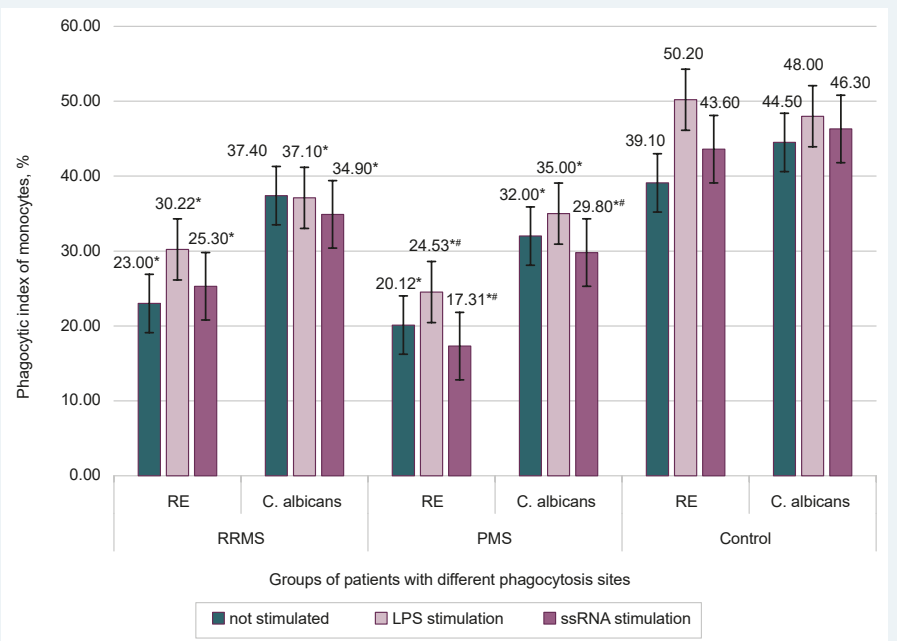

Fig. 2. Phagocytic number of peripheral blood monocytes relative to ram erythrocytes and $C$. albicans in patients with different types of MS.

*: $\mathrm{P}<0.05$ when compared with control group; \#: $\mathrm{P}<0.05$ when compared between patients with recurrent remitting MS and progressive MS

the type of multiple sclerosis the patients were divided into two groups: 58 patients with relapsing-remitting MS (RRMS) and 36 patients with progressive MS (PMS). The biological material was blood samples from patients with multiple sclerosis and healthy subjects. All persons who participated in the study voluntarily gave their written consent to participate in the study.

In patients with RRMS, biological material was taken immediately prior to initiation of treatment and after completion of the annual course of treatment with recombinant human IFN- $\beta$ "Betfer-1a" (Biopharma, Ukraine), administered according to the standard scheme. Patients who had at least one recurrence and/or increased EDSS disability score of 1 point or more during the year were classified as non-responders, and treatment efficacy was considered unsatisfactory. Patients who had a 1-point decrease in
EDSS in the absence of MS relapses were classified as responders [14].

The Responder Group (MS (IFN+)) included 37 patients (64\%), the Non-Responder Group (MS (IFN-)) included 21 subjects.

Monocyte isolation was performed using a double percoll gradient (Sigma, USA) according to the method [15], adapted to small volumes of blood. The number of monocytes in suspension was determined by immunofluorescence method using anti-CD14-PE (EXBIO Praha, a.s., Czech Republic). The monocyte-enriched cell suspension was resuspended with complete RPMI medium with the addition of $1 \mu \mathrm{g} / \mathrm{ml} E$. coli lipopolysaccharide (LPS) or ssRNA40/LyoVec (Invivogen, USA) as TLR4 and TLR7/8 agonists, respectively, or without the addition of inducers (intact cells), obtaining the final concentration of cells in the wells of 96 -well plate $1 \times 10^{5} \mathrm{cells} / \mathrm{ml}$, and then incubated for 24 hours at $t=37^{\circ} \mathrm{C}$ under an atmosphere of $5 \% \mathrm{CO}_{2}$.

Phagocytosis object was used in parallel series sensitized with hemolytic serum of ram erythrocytes (RE) and inactivated cells of 18 -hour $C$. albicans culture, the incubation time was 30 minutes. At microscopic examination of the dyed preparations 200 monocytes were counted. The phagocytic index (Phl) was calculated as the percentage of phagocytic monocytes and the phagocytic number $(\mathrm{PhN})$ as the ratio of the total number of absorbed REs or $C$. albicans cells to the number of monocytes entering phagocytosis (standard units) [15].

The obtained data were statistically processed using Statistica 11.0 (StatSoft, Inc.) and XLSTAT 19.6 (Addinsoft) software. The Mann-Whitney test was used to determine the significance of differences between the indices in the studied samples of RRMS and PMS, and the Wilcoxon test was used when comparing the indices before and after treatment. The data in the text, figures and tables are presented in the form of arithmetic mean and standard deviation: $\mathrm{M} \pm \mathrm{SD}$.

\section{Results}

The study of phagocytic activity of peripheral blood monocytes in patients with different types of the course and different treatment efficacy was performed by modeling their activation by agonists, namely: E. coli lipopolysaccharides for TLR4, and ssRNA for TLR7/8.

The first stage of our study implied the assessment of the phagocytic activity of peripheral blood monocytes in patients with multiple sclerosis, depending on the form of the disease: recurrent remitting MS and progressive MS.

Regardless of the type of disease course in all patients with MS, abnormalities of phagocytic activity of non-stimulated monocytes were detected, indicating a simultaneous decrease in phagocytic number, as well as the number of cells capable of phagocytosis mediated, both to mannose receptors and to FcR receptors (Fig. 1, 2).

Stimulation of the Fc receptor in the group with recurrent type of disease using LPS resulted in an increase in Phl and PhN by 1.3 times ( $P<0.05)$, and ssRNA40/LyoVec stimulation was associated with a two-fold increase in PM $(P<0.05)$. While in the group with progressive multiple sclerosis LPS and ssRNA40/LyoVec stimulation did not lead to significant changes in phagocytic activity 
against intact monocytes in the study of phagocytosis against sensitized ram erythrocytes (Fig. 1, 2).

Assessment of indices of phagocytosis mediated by the mannose receptor revealed a decrease in phagocytic activity of intact monocytes in patients with progressive MS. At the same time, no significant differences in phagocytic activity were observed in the group with recurring remitting type of MS compared with the control group. Stimulation of cells by TLR4 and TLR7/8 agonists was not accompanied by significant changes in phagocytic index relative to non-stimulated cells, however, the $\mathrm{Phl}$ in both groups was significantly lower than in the control group $(P<0.05)$. The $\mathrm{PhN}$ index in the group of patients with RRMS with cell stimulation did not differ from the control, and in the group of patients with $\mathrm{PMS}$ was significantly lower in comparison with the RRMS group and control, $\mathrm{P}<0.05$ (Fig. 1, 2).

There is likely a number of mechanisms underlying the pathogenesis of multiple sclerosis that have common patterns that determine the effectiveness of multiple sclerosis therapy, especially when using IFN- $\beta$ and other agents.

In the next step, we conducted a study of phagocytic activity of peripheral blood monocytes in patients with RRMS who received IFN- $\beta$ therapy. Depending on the established efficacy of treatment, the patients were divided into two groups: MS (IFN+) responders and MS (IFN-) non-responders (Table 1, 2).

Evaluation of phagocytosis indices in patients with RRMS prior to treatment revealed significant inhibition mediated through the mannose receptor and especially through the FcR fragment of monocyte phagocytic responses. In addition, there was a decrease in the $\mathrm{Phl}$ and $\mathrm{PhN}$ indices of non-stimulated monocytes both in the responders and in the non-responders (Table 1, 2).

In the "responders" group, $\mathrm{Phl}$ was reduced relative to control by 1.75 times, PhN by 1.77 times, a corresponding decrease in phagocytic reactions was also observed in the "non-responders" group by 1.69 times and 2.07 times $(P<0.05)$. The Phl and PhN indicators of TLR4and TLR7/8-activated monocytes in the responder and non-responder groups were also significantly lower than in the healthy subjects. When stimulated with ssRNA40/ LyoVec and with LPS, Phl indicators remained below control $(P<0.05)$ (Table 1, 2).

After treatment in the MS (IFN+) group, there was an increase in the intact monocyte $\mathrm{Phl}$ and $\mathrm{PhN}$ against the control group $(P<0.05)$. In FCR-mediated phagocytosis in TLR4-stimulated monocytes, there was a 1.42-fold increase in Phl after treatment and a 1.33-fold increase in PhN. At the same time, TLR7/8 stimulation resulted in a more pronounced increase in Phl, almost 2-fold, and a 1.18-fold increase in $\mathrm{PhN}$ (Table 1, 2).

As for MS (IFN-) patients who showed poor IFN- $\beta$ treatment results, $\mathrm{Phl}$ and $\mathrm{PhN}$ indices of non-stimulated monocytes remained lower relative to controls $(P>0.05)$. After TLR4 and TLR7/8 stimulation, the Phl values in this group remained significantly lower than the phagocytosis indices in the control group, and were also significantly lower than in the corresponding MS (IFN+) group. When stimulated with ssRNA40/LyoVec, the PhN remained lower than in the control group $(P<0.05)$. On the other hand, the $\mathrm{PhN}$ stimulation index did not differ from that of the MS (IFN+) group and control group (Table 1, 2).
Table 1. Indicators of phagocytic activity of peripheral blood monocytes against ram erythrocytes in patients with RRMS, depending on the effectiveness of treatment, $(\mathrm{M} \pm \mathrm{SD})$

\begin{tabular}{|c|c|c|c|c|c|c|}
\hline \multirow[t]{3}{*}{ Series } & \multirow{3}{*}{$\begin{array}{l}\text { Indi- } \\
\text { ces }\end{array}$} & \multicolumn{4}{|c|}{ Groups of patients } & \multirow[t]{3}{*}{ Control } \\
\hline & & \multicolumn{2}{|c|}{ Before treatment } & \multicolumn{2}{|c|}{ After treatment } & \\
\hline & & Responders & $\begin{array}{l}\text { Non- } \\
\text { responders }\end{array}$ & Responders & $\begin{array}{l}\text { Non- } \\
\text { responders }\end{array}$ & \\
\hline \multirow{2}{*}{$\begin{array}{l}\text { not } \\
\text { stimulated }\end{array}$} & Phl, \% & $22.4 \pm 2.1^{* \#}$ & $23.1 \pm 3.6^{*}$ & $37.0 \pm 1.4^{\#, \S}$ & $26.7 \pm 4.5^{*}, \S$ & $39.1 \pm 2.4$ \\
\hline & $\begin{array}{l}\mathrm{PhN}, \\
\mathrm{pc}\end{array}$ & $1.84 \pm 0.12^{\star}$ & $1.57 \pm 0.22^{*}$ & $3.77 \pm 0.14^{\#, \S}$ & $2.13 \pm 0.21^{*} \S$ & $3.25 \pm 0.20$ \\
\hline \multirow{2}{*}{$\begin{array}{l}\text { LPS } \\
\text { stimulation }\end{array}$} & Phl, \% & $29.5 \pm 1.8^{*} \#$ & $25.3 \pm 2.4^{* \star *}$ & $46.4 \pm 4.1^{\#, \S}$ & $34.5 \pm 2.6^{* * *}, \S$ & $50.2 \pm 4.5$ \\
\hline & $\begin{array}{l}\mathrm{PhN}, \\
\mathrm{pc}\end{array}$ & $2.75 \pm 0.21^{*}$ & $2.03 \pm 0.31^{\star}$ & $3.58 \pm 0.26^{\#}$ & $2.98 \pm 0.34$ & $3.89 \pm 0.30$ \\
\hline \multirow{2}{*}{$\begin{array}{l}\text { SsRNA } \\
\text { stimulation }\end{array}$} & Phl, \% & $24.1 \pm 2.2^{*} \#, \S$ & $18.7 \pm 2.9^{*+*, \S}$ & $49.1 \pm 3.5^{\#, \S}$ & $23.9 \pm 2.2^{*, * *}, \S$ & $43.6 \pm 2.8$ \\
\hline & $\begin{array}{l}\mathrm{PhN}, \\
\mathrm{pc}\end{array}$ & $3.21 \pm 0.12^{*} \#, \S$ & $1.74 \pm 0.31^{*} \S$ & $4.26 \pm 0.15^{\S}$ & $2.16 \pm 0.35^{\star}, \S$ & $4.08 \pm 0.20$ \\
\hline
\end{tabular}

*: $\mathrm{P}<0.05$ when compared with control group; \#: $\mathrm{P}<0.05$ when compared with MS (IFN+) results before and after treatment; **: $\mathrm{P}<0.05$ when compared with MS (IFN-) results before and after treatment; §: $\mathrm{P}<0.05$ when compared between MS (IFN+) and MS (IFN-) patients.

Table 2. Indicators of phagocytic activity of peripheral blood monocytes against $C$. albicans in patients with RRMS, depending on the effectiveness of treatment, $(\mathrm{M} \pm \mathrm{SD})$

\begin{tabular}{|c|c|c|c|c|c|c|}
\hline \multirow[t]{3}{*}{ Series } & \multirow{3}{*}{$\begin{array}{l}\text { Indi- } \\
\text { ces }\end{array}$} & \multicolumn{4}{|c|}{ Groups of patients } & \multirow[t]{3}{*}{ Control } \\
\hline & & \multicolumn{2}{|c|}{ Before treatment } & \multicolumn{2}{|c|}{ After treatment } & \\
\hline & & Responders & $\begin{array}{l}\text { Non- } \\
\text { responders }\end{array}$ & Responders & $\begin{array}{l}\text { Non- } \\
\text { responders }\end{array}$ & \\
\hline \multirow{2}{*}{$\begin{array}{l}\text { not } \\
\text { stimulated }\end{array}$} & Phl, \% & $36.1 \pm 1.5^{*}$ & $31.8 \pm 2.2^{*}$ & $34.4 \pm 3.1^{*}$ & $31.5 \pm 4.1^{*}$ & $44.5 \pm 2.3$ \\
\hline & $\begin{array}{l}\mathrm{PhN}, \\
\mathrm{pc}\end{array}$ & $3,5 \pm 0.2^{\#}$ & $3.12 \pm 0.20^{*}$ & $4.35 \pm 0.30^{\#, \S}$ & $3.27 \pm 0.20^{*}$ & $3.93 \pm 0.20$ \\
\hline \multirow{2}{*}{$\begin{array}{l}\text { LPS } \\
\text { stimulation }\end{array}$} & Phl, \% & $36.9 \pm 2.3^{*}$ & $35.3 \pm 4.2^{*}$ & $39.1 \pm 1.6^{*}$ & $37.2 \pm 3.1^{*}$ & $48.0 \pm 2.1$ \\
\hline & $\begin{array}{l}\mathrm{PhN}, \\
\mathrm{pc}\end{array}$ & $4,17 \pm 0.10^{\#}$ & $3.94 \pm 0.20$ & $5.06 \pm 0.16^{\#, \S}$ & $4.15 \pm 0.30^{\S}$ & $4.52 \pm 0.30$ \\
\hline \multirow{2}{*}{$\begin{array}{l}\text { ssRNA } \\
\text { stimulation }\end{array}$} & Phl, \% & $35.8 \pm 1.9^{*} \#, \S$ & $30.2 \pm 3.1^{* * *,}, \S$ & $40.5 \pm 1.5^{\#, \S}$ & $48.8 \pm 4.5^{\star \star}, \S$ & $46.3 \pm 3.2$ \\
\hline & $\begin{array}{l}\mathrm{PhN}, \\
\mathrm{pc}\end{array}$ & $4.8 \pm 0.2^{\S}$ & $3.35 \pm 0.30^{*} .8$ & $5.24 \pm 0.20^{\S}$ & $3.21 \pm 0.20 * \S$ & $4.91 \pm 0.30$ \\
\hline
\end{tabular}

*: $\mathrm{P}<0.05$ when compared with control group; \#: $\mathrm{P}<0.05$ when compared with $\mathrm{MS}(\mathrm{IFN}+)$ results before and after treatment; **: $\mathrm{P}<0.05$ when compared with MS(IFN-) results before and after treatment; §: $\mathrm{P}<0.05$ when compared between MS (IFN+) and MS (IFN-) patients.

With respect to the indices of mannose receptor-mediated phagocytosis, there was a decrease in $\mathrm{Phl}$ of unstimulated and stimulated monocytes in patients with RRMS in the MS (IFN+) group, prior to treatment, in contrast to $\mathrm{PhN}$ indices that had no significant differences from controls. Non-responders had a decrease in the levels of Phl and $\mathrm{PhN}$ of non-stimulated and stimulated monocytes.

After treatment in both groups, Phl values of non-stimulated and stimulated with LPS monocytes remained reduced. After stimulation with TLR7/8 agonists, the phagocytic index of monocytes did not differ from that of the control group. In the MS (IFN-) group, the PhN values of non-stimulated and ssRNA40/LyoVec stimulated monocytes remained low and did not differ from those before treatment (Table 1, 2).

The phagocytic features of mononuclear cells detected in non-responders on the one hand may indicate the presence of excessive, pathologically associated activation of non-stimulated cells, and on the other hand, indicate their functional depletion. 


\section{Discussion}

Many studies have found that the association between the functional features of monocytes and their phenotype is not sufficiently conservative and is able to vary substantially both under physiological and pathological conditions $[4,16,17]$. Waschbisch A. et al. and Pinheiro C. et al. have shown that "classical", "intermediate" and "non-classical" monocytes have functional differences not only related to their properties, but also the specific ability to activate them in response to stimulation of MyD88-dependent TLRs of different types, in particular TLR4 and TLR7/8 [3,18]. Accordingly, we evaluated the composition of mononuclear cell subpopulations by influencing different types of TLR receptors. We have shown that activation of the Fc receptor of mononuclear cells by ssRNA40/LyoVec was stronger compared to the stimulating effect of LPS, possibly related to the involvement of a subpopulation of "non-classical" monocytes in phagocytosis.

Clarification of the role of peripheral blood monocytes in the pathogenesis of the disease, determination of appropriate immunophenotypes, according to some researchers may be of practical importance, in particular to be one of the criteria for predicting the effectiveness of therapy for stratification of patients with multiple sclerosis $[4,7,9,18,19]$. Zheng $S$. et al. have found out that the dysregulation of TLR7/8 signals on mononuclear cells may be considered as one of the key factors in the development of neuroinflammation in multiple sclerosis [7]. Hurtado-Guerrero I. et al. have demonstrated that TLR7 signaling mechanisms are disturbed in peripheral blood monocytes in patients with recurrent remitting disease [19]. The level of TLR7 expression on peripheral blood monocytes in MS patients was significantly reduced relative to mononuclear cells of healthy donors, and at the same time IFN- $\beta$ therapy led to an increase in TLR7 expression to healthy donor levels. These researchers have also shown that TLR7 transcription in dendritic cells of monocytic origin depends on endogenous IFN- $\beta$ production. A pattern has been revealed to indicate that impaired TLR7 expression in patients with RRMS is cell specific for the monocyte fraction of mononuclear cells, which also affects the production and modeling of IFN- $\beta$ by these cells. However, the level of TLR7 expression on B-lymphocytes in these patients does not differ from that of healthy donors $[9,18,19]$.

We have found a decrease in phagocytic activity of TLR4- and TLR7/8-activated monocytes in patients with recurrent remitting and progressive type of MS relative to healthy subjects $(P<0.05)$. The study has also shown a reduced reserve capacity of phagocytic mononuclear cells to LPS- and ssRNA-stimulated phagocytosis in patients with PMS compared with the corresponding RRMS group, $\mathrm{P}<0.05$ (Table 1, 2).

Therapy with recombinant interferon beta-1a in patients with RRMS resulted in the correction of phagocytic activity disorders in the responders, with TLR7/8-mediated monocyte activation accompanied by an increase in the number of phagocytic cells. In non-responders, the nature of changes in phagocytic activity of TLR4 and TLR7/8-stimulated monocytes indicated a decrease in functional reserve for FcR-mediated phagocytosis.
Thus, we believe that indicators of FcR-mediated phagocytosis of intact and TLR-activated monocytes can be used to predict the potential of non-responders in the treatment with IFN- $\beta$.

\section{Conclusions}

1. Modeling of TLR-dependent activation of monocytes and assessment of the functional state of intact and activated mononuclear cells allowed to obtain new data on the existence of functional-phenotypic heterogeneity of cells of the monocyte fraction of peripheral blood mononuclear cells, depending on the clinical form of its treatment.

2. As a result of a study of TLR4- and TLR7/8-mediated activation of cells of the monocyte fraction of peripheral blood mononuclear cells in patients with recurrent remitting and progressive type of MS, a decrease in phagocytic activity was observed, which was more significant in patients with PMS.

3. TLR-mediated stimulation of respondent monocytes in patients with RRMS after treatment was accompanied by an increase in the number of phagocytic cells, in contrast to non-responders. The nature of the changes in the phagocytic activity of stimulated monocytes indicated a decrease in their functional reserve in FcR-mediated phagocytosis.

Prospects for further research. The relevance of further studies of phagocytic responses of mononuclear cells with TLR-mediated activation in MS patients is undeniable. However, new progressive methods are needed to allow real-time detection of changes in the population of monocytes, their functional properties, and the ability to determine the level of $F c$ receptor expression on these cells. This will clarify the peculiarities of the functional status of monocytes of different subpopulations and their pathogenic role in the development and course of multiple sclerosis.

Funding

The study was financed from the state budget within the framework of the research and development program "Investigation of the role of virus-mediated activation of mononuclear phagocytes in multiple sclerosis" (state registration number 0120U100668) of the Laboratory of Clinical Immunology and Allergology of SI "I. Mechnikov Institute of Microbiology and Immunology of the National Academy of Medical Sciences of Ukraine".

Conflicts of interest: authors have no conflict of interest to declare. Конфлікт інтересів: віАсутній.

НаАійшла Ао редакції / Received: 08.04.2020

Після Аоопрацювання / Revised: 27.04.2020

Прийнято АО Аруку / Accepted: 04.05.2020

Information about authors:

Skliar A. I., MD, PhD, Researcher, Laboratory of Clinical Immunology and Allergology, SI “I. Mechnikov Institute of Microbiology and Immunology of the National Academy of Medical Sciences of Ukraine", Kharkiv, Ukraine.

ORCID ID: 0000-0002-8273-3739

Koliada O. M., MD, PhD, Associate Professor of D. O. Alpern Pathological Physiology Department, Kharkiv National Medical University, Ukraine.

ORCID ID: 0000-0003-2826-0667 
Vdovichenko N. I., Researcher, Laboratory of Clinical Immunology and Allergology, SI "I. Mechnikov Institute of Microbiology and Immunology of the National Academy of Medical Sciences of Ukraine", Kharkiv, Ukraine.

ORCID ID: 0000-0002-6952-9389

Koliada T. I., MD, PhD, DSc, Professor, Head of the Laboratory of Clinical Immunology and Allergology, SI "I. Mechnikov Institute of Microbiology and Immunology of the National Academy of Medical Sciences of Ukraine", Kharkiv, Ukraine.

ORCID ID: 0000-0002-4143-8514

\section{Відомості про авторів:}

Скляр А. І., канА. меА. наук, науковий співробітник лабораторії клінічної імунології та алергології, $А$ «॥нститут мікробіології та імунології імені І. І. Мечникова НАМН Україним, м. Харків. Коляда О. М., канА. меА. наук, Аоцент каф. патологічної фізіології імені А. О. Альперна, Харківський національний медичний університет, Україна.

ВАовіченко Н. І., науковий співробітник лабораторії кмінічної імунології та алергології, АУ «нститут мікробіології та імунології імені І. І. Мечникова НАМН України", м. Харків.

Коляда Т. І. А-р меА. наук, професор, зав. лабораторії кмінічної імунології та алергології, $\mathrm{A}$ « «нститут мікробіології та імунології імені І. І. Мечникова НАМН України", м. Харків.

\section{Сведения об авторах:}

Скляр А. И., канА. меА. наук, научный сотрудник лаборатории клинической иммунологии и амлергологии, ГУ “Институт микробиологии и иммунологии имени И. И. Мечникова НАМН Украины", г. Харьков.

КоляАа О. Н., канА. меА. наук, Аоцент каф. патологической физиологии имени А. Е. Альперна, Харьковский национальный меАицинский университет, Украина.

ВАовиченко Н. И., научный сотрудник лаборатории киинической иммунологии и амеергологии, ГУ «Институт микробиологии и иммунологии имени И. И. Мечникова НАМН Украины", г. Харьков.

КоляАа Т. И., А-р меА. наук, профессор, зав. лабораторией клинической иммунологии и амлергологии, ГУ «Институт микробиологии и иммунологии имени И. И. Мечникова НАМН Украины", г. Харьков.

\section{References}

[1] Baufeld, C., O'Loughlin, E., Calcagno, N., Madore, C., \& Butovsky, O. (2018). Differential contribution of microglia and monocytes in neurodegenerative diseases. Journal of neural transmission, 125(5), 809-826. https://doi.org/10.1007/s00702-017-1795-7

[2] Boyette, L. B., Macedo, C., Hadi, K., Elinoff, B. D., Walters, J. T., Ramaswami, B., Chalasani, G., Taboas, J. M., Lakkis, F. G., \& Metes, D. M. (2017). Phenotype, function, and differentiation potential of human monocyte subsets. PloS one, 12(4), e0176460. https://doi.org/10.1371

[3] Pinheiro, C., Monteiro, A., Dutra, F. F., Bozza, M. T., Peters-Golden, M., Benjamim, C. F., \& Canetti, C. (2017). Short-Term Regulation of FcyR-Mediated Phagocytosis by TLRs in Macrophages: Participation of 5-Lipoxygenase Products. Mediators of inflammation, 2017, 2086840. https://doi.org/10.1155/2017/2086840

[4] Gjelstrup, M. C., Stilund, M., Petersen, T., Møller, H. J., Petersen, E. L, \& Christensen, T. (2018). Subsets of activated monocytes and markers of inflammation in incipient and progressed multiple sclerosis. Immunology and cell biology, 96(2), 160-174. https://doi.org/10.1111/imcb.1025

[5] Jakubzick, C. V., Randolph, G. J., \& Henson, P. M. (2017). Monocyte differentiation and antigen-presenting functions. Nature reviews. Immunology, 17(6), 349-362. https://doi.org/10.1038/nri.2017.28

[6] Asadzadeh Manjili, F., Yousefi-Ahmadipour, A., \& Kazemi Arababadi, M. (2020). The roles played by TLR4 in the pathogenesis of multiple sclerosis; A systematic review article. Immunology letters, 220, 63-70. https://doi.org/10.1016/i.imlet.2020.02.004

[7] Zheng, C., Chen, J., Chu, F., Zhu, J., \& Jin, T. (2020). Inflammatory Role of TLR-MyD88 Signaling in Multiple Sclerosis. Frontiers in molecular neuroscience, 12, 314. https://doi.org/10.3389/fnmol.2019.00314

[8] Bhargava, P., Nogueras-Ortiz, C., Chawla, S., Bæk, R., Jørgensen, M. M., \& Kapogiannis, D. (2019). Altered Levels of Toll-Like Receptors in Circulating Extracellular Vesicles in Multiple Sclerosis. Cells, 8(9), 1058. https://doi.org/10.3390/cells8091058

[9] Deckx, N., Willekens, B., Wens, I., Eijnde, B. O., Goossens, H., Van Damme, P., Berneman, Z. N., \& Cools, N. (2016). Altered molecular expression of TLR-signaling pathways affects the steady-state release of IL-12p70 and IFN- $\alpha$ in patients with relapsing-remitting multiple sclerosis. Innate immunity, 22(4), 266-273. https://doi. org/10.1177/1753425916642615

[10] Bender, A. T., Tzvetkov, E., Pereira, A., Wu, Y., Kasar, S., Przetak, M. M. Vlach, J., Niewold, T. B., Jensen, M. A., \& Okitsu, S. L. (2020). TLR7 and TLR8 Differentially Activate the IRF and NF-KB Pathways in Specific Cell Types to Promote Inflammation. ImmunoHorizons, 4(2), 93-107. https://doi.org/10.4049/immunohorizons.2000002

[11] Golden, R. (2018). AReview of Multiple Sclerosis Treatments: Interferon Beta, Glatiramer Acetate, Fingolimod, and Natalizumab. Biology and Microbiology Graduate Students Plan B Research Projects. 3. https:I/ openprairie.sdstate.edu/biomicro plan-b/3

[12] Chuluundori. D., Harding, S. A., Abernethy, D. \& La Flamme, A. C. (2017). Glatiramer acetate treatment normalized the monocyte activation profile in MS patients to that of healthy controls. Immunology and cell biology, 95(3), 297-305. https://doi.org/10.1038/icb. 2016.99

[13] Kzhyshkowska, J., Gudima, A., Moganti, K., Gratchev, A., \& Orekhov, A. (2016). Perspectives for Monocyte/Macrophage-Based Diagnostics of Chronic Inflammation. Transfusion medicine and hemotherapy, 43(2), 66-77. https://doi.org/10.1159/000444943

[14] Bustamante, M. F., Morcillo-Suárez, C., Malhotra, S., Rio, J., Leyva, L., Fernández, O., ... Comabella, M. (2015). Pharmacogenomic study in patients with multiple sclerosis. Neurology - Neuroimmunology Neuroinflammation, 2(5), e154. https://doi.org/10.1212/nxi.0000000000000154

[15] Editors: Rousselet, G. (Ed.) (2018). Macrophages. Methods and Protocols. In Methods in Molecular Biology. Humana Press. https:ll doi.org/10.1007/978-1-4939-7837-3

[16] Metcalf, T. U., Wikinson, P. A., Cameron, M. J., Ghneim, K., Chiang, C., Wertheimer, A. M., Hiscott, J. B., Nikolich-Zugich, J., \& Haddad, E. K. (2017). Human Monocyte Subsets Are Transcriptionally and Functionally Altered in Aging in Response to Pattern Recognition Receptor Agonists. Journal of immunology (Baltimore, Md. : 1950), 199(4), 1405-1417. https://doi.org/10.4049/immunol.1700148

[17] González-Oria, M. C., Márquez-Coello, M., Girón-Ortega, J. A., Argente, J., Moya, M., \& Girón-González, J. A. (2019). Monocyte and Lymphocyte Activation and Regulation in Multiple Sclerosis Patients. Therapy Effects. Journal of neuroimmune pharmacology : the official journal of the Society on Neurolmmune Pharmacology, 14(3), 413-422. https://doi.org/10.1007/s11481-018-09832-z

[18] Waschbisch, A., Schröder, S., Schraudner, D., Sammet, L., Weksler, B. Melms, A., Pfeifenbring, S., Stadelmann, C., Schwab, S., \& Linker, R. A. (2016). Pivotal Role for CD16+ Monocytes in Immune Surveillance of the Central Nervous System. Journal of immunology (Baltimore, Md. : 1950), 196(4), 1558-1567. https://doi.org/10.4049/iimmunol.1501960

[19] Hurtado-Guerrero, I., Pinto-Medel, M. J., Urbaneja, P., Rodriguez-Bada, J. L., León, A., Guerrero, M., Fernández, Ó., Leyva, L., \& Oliver-Martos, B. (2017). Activation of the JAK-STAT Signaling Pathway after In Vitro Stimulation with IFNß in Multiple Sclerosis Patients According to the Therapeutic Response to IFNB. PloS one, 12(1), e0170031. https:// doi.org/10.1371/journal.pone.0170031 